\title{
A Preliminary Assessment of the Role of Ambient Nitric Oxide Exposure in Hospitalization with Respiratory Syncytial Virus Bronchiolitis
}

\author{
Nuredin I. Mohammed ${ }^{1}$, Mark L. Everard ${ }^{2}$, Jon G. Ayres ${ }^{1}$, Nicola J. Barker ${ }^{3}$ \\ and Ian J. Litchfield ${ }^{1, *}$ \\ 1 Institute of Applied Health Research, College of Medical and Dental Sciences, University of Birmingham, \\ Birmingham B15 2TT, UK; nim007@bham.ac.uk (N.I.M.); j.g.ayres@bham.ac.uk (J.G.A.) \\ 2 School of Paediatrics and Child Health, University of Western Australia, WA 6009, Australia; \\ mark.everard@uwa.edu.au \\ 3 Sheffield Children's NHS Foundation Trust, Respiratory Medicine, Sheffield S10 2TH, UK; \\ nicki.barker@sch.nhs.uk \\ * Correspondence: I.Litchfield@bham.ac.uk; Tel.: +44-(0)-121-414-6006
}

Academic Editors: Helena Solo-Gabriele and Alesia Ferguson

Received: 23 February 2016; Accepted: 30 May 2016; Published: 9 June 2016

\begin{abstract}
Some in vitro studies have indicated a possible link between respiratory syncytial virus (RSV) infection and exposure to Nitric Oxide (NO). However, these studies used much higher NO concentrations than normally found in the ambient environment. This preliminary study explored whether an association was present with short-term exposure to NO in the environment. RSV-related admission data between November 2011 and February 2012 were obtained from Sheffield Children's Hospital. The dates of admission were linked to contemporaneous ambient NO derived from sentinel air monitors. The case-crossover design was used to study the relationship between daily RSV admissions and NO, controlling for temperature and relative humidity. We found little evidence of association between daily RSV admission rates and exposure to ambient NO at different lags or average exposure across several lags. The findings should, however, be viewed with caution due to the low number of events observed during the time frame. It is possible that the apparent lack of association may be accounted for by the timing of the seasonal RSV epidemic in relation to peaks in NO concentrations. A larger study incorporating a wider range of RSV and NO peaks would determine whether said peaks enhanced the number of RSV hospitalizations in children.
\end{abstract}

Keywords: respiratory syncytial virus; bronchiolitis; air pollution; nitrogen oxide

\section{Introduction}

Acute lower respiratory tract infections are the leading cause of child morbidity and mortality globally. Of the viral pathogens responsible, respiratory syncytial virus (RSV) is deemed one of the most significant $[1,2]$. The human respiratory syncytial virus is a paramyxovirus closely related to bovine and ovine RSV. It is believed to be transmitted via inhalation of droplets generated by coughing or self-inoculation into eyes and nose from contaminated hands. The virus only remains viable outside the human host for a short period [2,3]. Though the exact contribution of RSV is uncertain, it has been estimated that annually it is responsible for up to 200,000 deaths [4]. Figures from the UK indicate that RSV is the commonest cause of severe respiratory illness in young children aged under 2 years; it is also the most frequent cause of hospital admissions due to acute respiratory illness in young children, with over 8900 positive tests recorded by the Health Protection Agency (HPA) from October to March during 2012/2013 [5]. 
In temperate regions, annual epidemics of RSV-related infections typically follow a seasonal trend peaking during winter, while in tropical regions the epidemics are generally associated with the rainy season. A number of demographic factors have been associated with increased risk of RSV-related diseases including sex, age, birth during RSV season, siblings/crowding and previous RSV infection [6-9]. Due to the highly seasonal pattern of annual epidemics, meteorological factors such as temperature, hours of sunlight and humidity have been considered as potentially being related to RSV, but findings have been inconsistent, suggesting that such factors may not be affecting the incidence or severity of disease directly. Increased incidence of hospitalization has also been reported among infants living in industrialised areas compared to urban and rural areas [10,11] giving rise to the suggestion that there may be a link between certain air pollutants and severity of illness. Again, results from studies addressing this possibility have not been consistent [12-15].

One pollutant that has been little explored is nitric oxide (NO), which is known to be elevated during the winter compared to the summer season. These elevated levels of NO in winter may be due to reduced mixing of the lower air boundary during the winter months, and are further enhanced by reduced photochemical activity and behavioural changes due to the reduction in temperature [16]. A previous publication indicated that there may be a correlation between environmental levels of $\mathrm{NO}$ and admissions to hospital but this utilised aggregated data that were not subject to detailed analysis [17].

$\mathrm{NO}$ is of interest in the context of RSV infection for a number of reasons. In vitro work has shown that RSV infects macrophages and dendritic cells [18-20], two cells pivotal in orchestrating the immune response within the lungs and airways. Moreover, it has been shown that RSV may remain within the dendritic cell population in a latent form for prolonged periods. Reactivation of replication can be induced by exposing dendritic cells to $\mathrm{NO}$ at $600 \mathrm{ppb}$ for two hours or by adding the NO donor S-nitroso- $N$-acetylpenicillamine (SNAP) $[19,21]$. RSV has been shown to up-regulate iNOS and nitrite production in a cell line affecting ion channel function and aspects of inflammation including up-regulating NF-kB [22]. In a rodent model of RSV infection in infants, administering an iNOS inhibitor to the young mice resulted in increased viral titres in bronchoalveolar lavage (BAL) samples though inflammation was reduced [23]. NO has also been shown to play important roles in host responses to the virus, affecting immune responses and apoptosis of host cells [24,25]. The present epidemiological study exploring the relationship between RSV and short-term exposure to ambient NO pollution was undertaken with the aim of exploring the possibility that environmental nitric oxide influences the severity of the clinical illness experienced by infants with RSV infection and hence the rates of hospitalization.

\section{Materials and Methods}

\subsection{Health Data}

Data on daily admission of infants due to RSV infection were obtained from Sheffield Children's Hospital (Sheffield Children's NHS Foundation Trust) over a four month period (November 2011 to February 2012). Infection status was determined based on a positive test for RSV using a polymerase chain reaction (PCR) on nasopharyngeal aspirates. Few if any children with a simple upper respiratory tract infection are admitted to hospital and the study only addressed those admitted with a significant lower respiratory tract infection. All such children had a nasal sample taken for virus identification. In addition, date of birth, gender and date of admission (date of sampling) were provided for each child admitted to the hospital. Parents provided informed consent to participate in the study and ethical approval was obtained from Yorkshire and the Humber-Sheffield research ethics committee, National Research Ethics Service (NRES REC: 10/H1307/114). 


\subsection{NO Concentration Data}

Corresponding data on ambient NO concentrations were drawn from three sentinel monitors managed and maintained by the Department for the Environment, Food and Rural Affairs (DEFRA) which provide hourly concentrations of NO for each $24 \mathrm{~h}$ period. Details on techniques of analysis, methods of sampling, precision and accuracy of measurements can be found from the DEFRA website [26]. One of the stations, Sheffield Centre, was an urban monitor located in the centre of Sheffield city. The second station, Sheffield Tinsley, was in a relatively industrial site about three miles north west of the city centre, while the third station, Ladybower, was located in a rural site some ten miles to the east of Sheffield city centre. Thus oxides of nitrogen sources in Sheffield are mainly from road traffic and industrial emissions. We presented descriptive statistics for all three sites but our statistical models were based on the daily average NO concentrations from the three monitors in Sheffield.

\subsection{Climate Data}

Data on daily minimum and maximum temperature for Sheffield were obtained from the Met office British Atmospheric Data Centre (BADC) [27]. The average daily temperature for the study was then calculated by taking the average of the minimum and maximum temperatures. In addition, data on daily levels of relative humidity were also obtained from the Met office.

\subsection{Statistical Analysis}

The case-crossover design was used to investigate the association between short-term exposure to NO and the occurrence of RSV admissions controlling for average daily temperature and relative humidity. This design, introduced by Maclure [28], has been widely applied in air pollution studies and is particularly useful for estimating the risk of a rare acute outcome associated with short-term exposure [29-32]. In case-crossover design, each case acts as their own control and like case-control studies [33] the distribution of exposure is compared between "cases" and "controls". That is, exposure at the time just prior to the event ("case" or "index" time) is compared with a set of "control" times that represent the expected distribution of exposure for non-event follow-up times. The design helps primarily to control for confounding by subject-specific factors which do not change over time such as ethnicity and gender.

We applied the time stratified case-crossover approach where the strata are matching days based on the same day of the week, calendar month and year. That is, control days were selected from the same day of the week, within the same calendar month and year as the event day. Usually, analyses based on this design are carried out using a conditional logistic regression model. However, we applied a conditional Poisson regression model which has been shown to give estimates equivalent to the conditional logistic model [34]; the conditional Poisson model has the advantage of easily allowing for overdispersion and autocorrelation. All our models assume a linear effect of NO on RSV admissions while the effects of temperature and relative humidity are likely to be non-linear $[35,36]$ and were modelled using natural cubic splines with three degrees of freedom. We explored various lag structures including single lags $0,1,2, \ldots, 6$ and corresponding average of lags $0-1,0-2,0-3, \ldots$, 0-6 for NO exposure. Additional sensitivity analysis was conducted using NO data from Sheffield Central monitoring station to compliment the primary analysis which was based on the average NO levels from the three stations. All analyses were performed using the R statistical package [37].

\section{Results}

The average number of admissions per day was 1.7 and occurred in only 79 days of the study period, which spaned four months (Table 1). The mean age of a child admitted to the hospital was a little over 4 months (133 days) and all children were under the age of one year except one child who was a year and half old. Of the total admitted children, 99 (46.7\%) were females and $109(52.4 \%)$ were 
males. The peak admission counts were observed at the end of November and beginning of December as shown in Figure 1 (grey solid line) and did not seem to coincide with those peaks for the average NO concentrations which were observed in January and February.

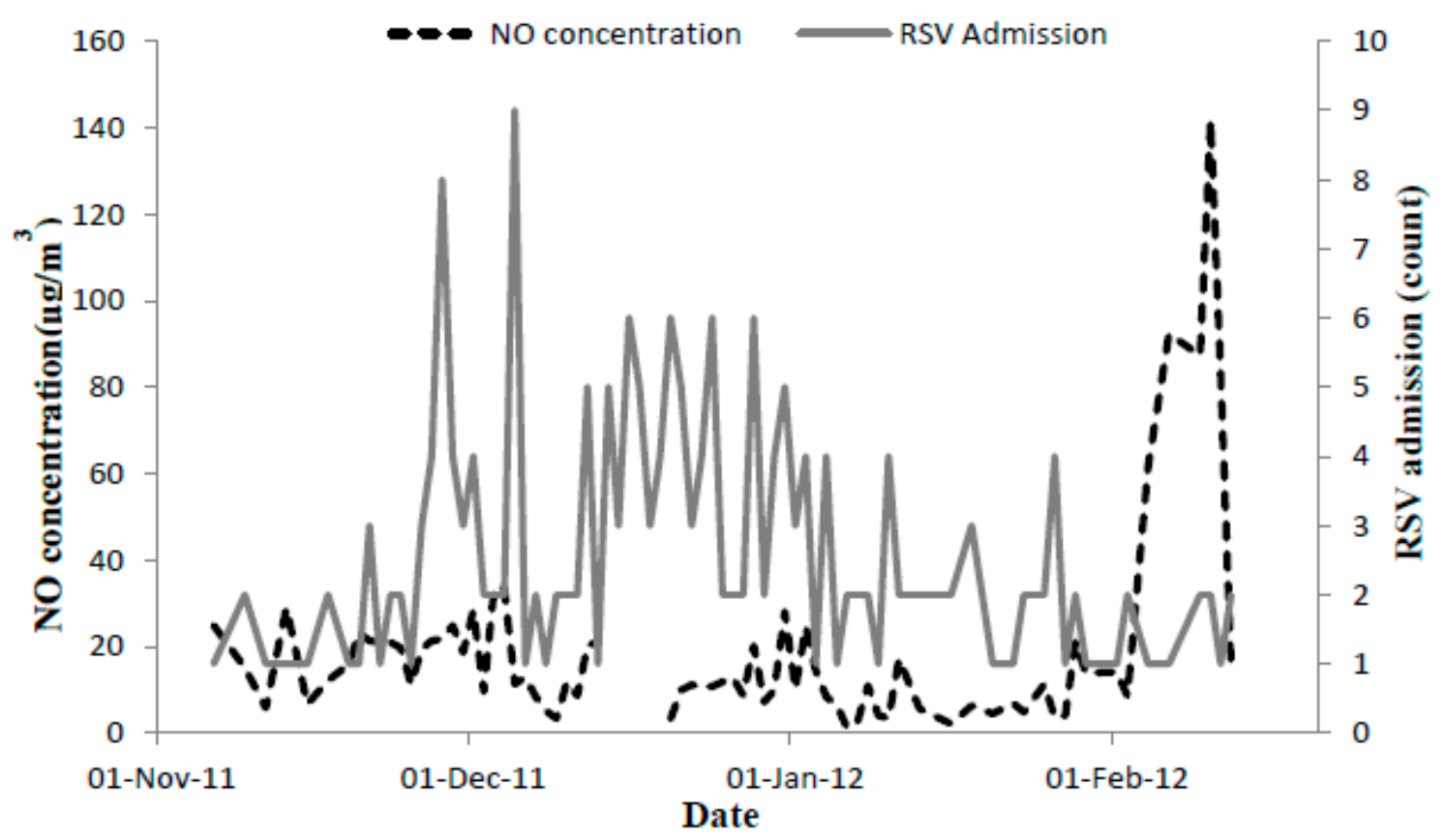

Figure 1. Average NO concentrations and RSV related admissions at Sheffield Children's Hospital.

Table 1. Summary for daily admission counts and NO concentration by monitoring station.

\begin{tabular}{cccccc}
\hline Variable & Mean & Median $\left(\mathbf{I Q R}^{\mathbf{b}}\right.$ ) & Minimum & Maximum & Number of Days \\
\hline Age (days) & $132.7(101)$ & $111(43-189)$ & 7 & 573 & 121 \\
Admission count & $1.7(1.9)$ & $1(0-2)$ & 0 & 9 & 121 \\
Temperature $\left({ }^{\circ} \mathrm{C}\right)$ & $6.3(3.6)$ & $6.7(3.6-9.1)$ & -2.3 & 13.3 & 121 \\
Relative humidity $(\%)$ & $80.3(11.4)$ & $81.8(72-88.5)$ & 41.8 & 98 & 101 \\
NO $\left(\mu \mathrm{g} / \mathrm{m}^{3}\right)$ & & & & & \\
Sheffield Centre & $26.4(31.7)$ & $16.6(5.1-36.8)$ & 1 & 173.2 & 120 \\
Sheffield Tinsley & $25.8(35.1)$ & $15.7(6.9-28.4)$ & 1.3 & 267.9 & 121 \\
Ladybower & $3.2(2.1)$ & $2.5(1.6-4.2)$ & 0.6 & 12.9 & 115 \\
Average & $18.6(20.7)$ & $11.8(7.2-21.1)$ & 1.3 & 141.8 & \\
Sex (N, \%) & & & & & \\
Female & $99(47.6)$ & & & & \\
\hline
\end{tabular}

${ }^{\mathrm{a}}$ Number, percent; ${ }^{\mathrm{b}}$ Interquartile range.

Most children admitted to Sheffield Children's Hospital due to RSV infection were from locations surrounding central Sheffield, where the hospital itself as well as the central monitoring station are located (Figure 2).

As expected, NO concentrations were much lower at the rural Ladybower station while the urban Sheffield Centre and Sheffield Tinsley had more or less similar concentrations over the study period. For all the three stations, NO levels tend to show peaks in February (Figure 3). NO concentration data were missing for six days in Ladybower and one day for Sheffield Central stations. Relative humidity data were also missing for twenty days. 


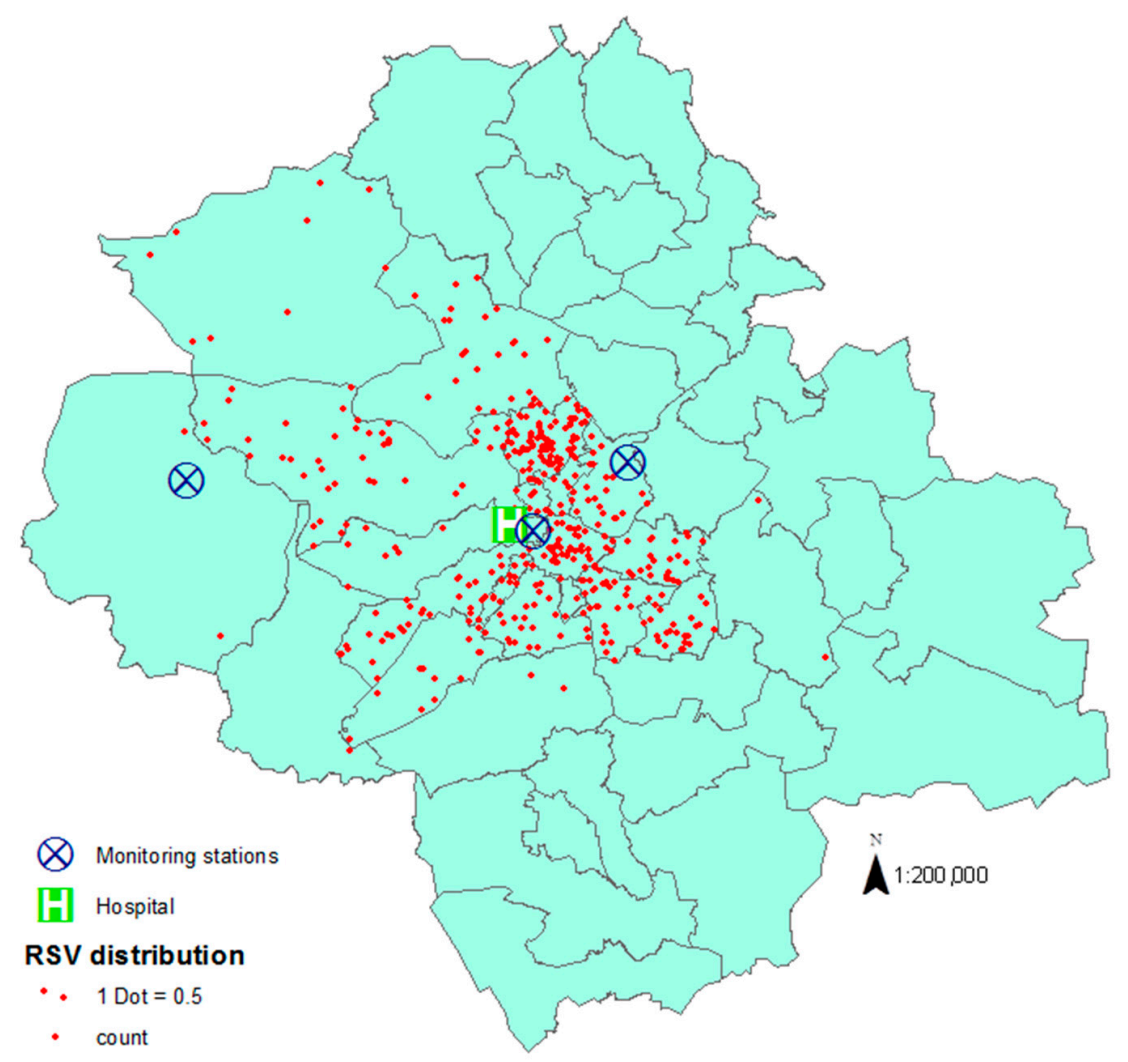

Figure 2. Distribution of RSV infected cases admitted to Sheffield Children's Hospital and location of monitoring stations.

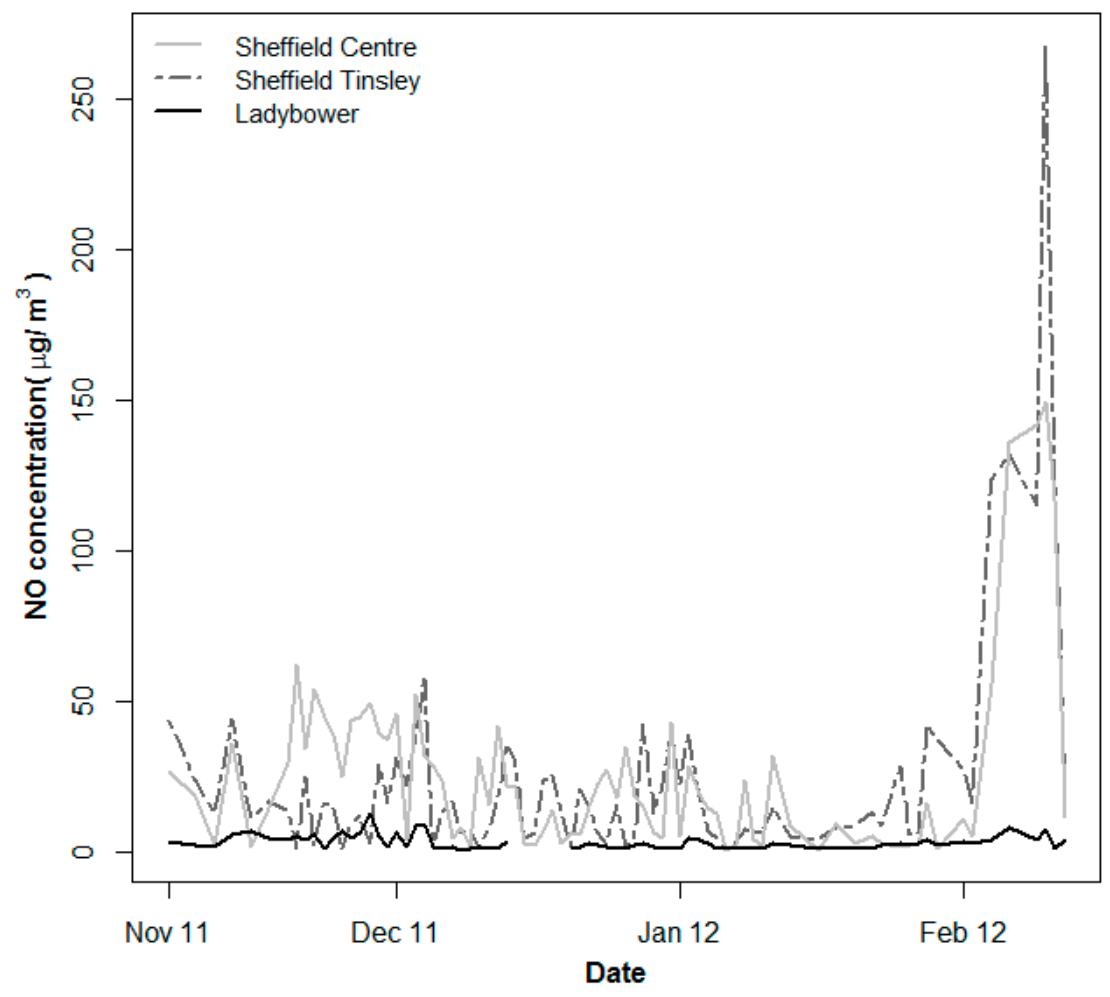

Figure 3. NO concentrations for the three monitoring stations around Sheffield city over the study period November 2011-February 2012. 
Overall, we did not find evidence of association between daily RSV admission rates and ambient NO concentrations in Sheffield; for example, the odds ratio (OR) $(95 \%$ confidence interval (CI)) associated with a $10 \mu \mathrm{g} / \mathrm{m}^{3}$ increase in previous day (lag 1$) \mathrm{NO}$ concentration was $0.93(0.82,1.05)$ after controlling for non-linear effects of temperature and relative humidity. Results were similar across the various single lags and corresponding average of lags considered (Figure 4).

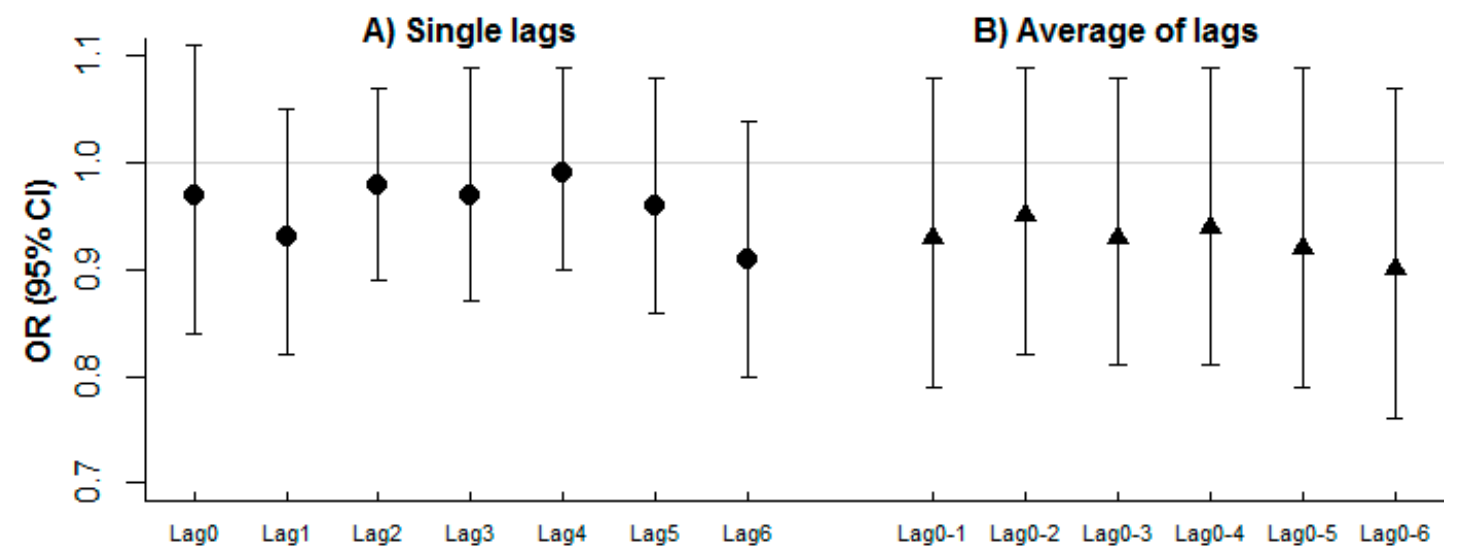

Figure 4. OR (95\% CI) for the association of daily RSV admission and average NO concentrations in Sheffield. (A) Single lags; (B) Average of lags.

The results presented above were based on average NO exposure data from three stations, namely Sheffield Centre (urban site), Sheffield Tinsley (industrial site) and Ladybower (rural site) which had six missing observations. A sensitivity analysis using NO data from Sheffield Central monitoring station, which had only one missing observation, provided qualitatively similar results with no evidence of association and did not affect the overall conclusions (Table 2).

Table 2. Association between NO and RSV admissions using data from a central monitoring station vs. average NO concentration from three monitoring stations.

\begin{tabular}{ccccc}
\hline \multirow{2}{*}{ Metric } & \multicolumn{2}{c}{ Sheffield Centre } & \multicolumn{2}{c}{ Average * } \\
\cline { 2 - 5 } & OR (95\% CI) & $p$-Value & OR (95\% CI) & $p$-Value \\
\hline Lag 0 & $0.94(0.85,1.04)$ & 0.23 & $0.97(0.84,1.11)$ & 0.62 \\
Lag 1 & $0.98(0.91,1.05)$ & 0.57 & $0.93(0.82,1.05)$ & 0.23 \\
Lag 2 & $0.99(0.92,1.05)$ & 0.69 & $0.98(0.89,1.07)$ & 0.59 \\
Lag 3 & $1.01(0.95,1.07)$ & 0.80 & $0.97(0.87,1.09)$ & 0.62 \\
Lag 4 & $0.99(0.93,1.06)$ & 0.80 & $0.99(0.9,1.09)$ & 0.85 \\
Lag 5 & $1.0(0.93,1.08)$ & 0.97 & $0.96(0.86,1.08)$ & 0.51 \\
Lag 6 & $0.96(0.88,1.04)$ & 0.27 & $0.91(0.8,1.04)$ & 0.16 \\
Lag 0-1 & $0.94(0.85,1.04)$ & 0.27 & $0.93(0.79,1.08)$ & 0.33 \\
Lag 0-2 & $0.95(0.87,1.05)$ & 0.34 & $0.95(0.82,1.09)$ & 0.45 \\
Lag 0-3 & $0.96(0.87,1.06)$ & 0.40 & $0.93(0.81,1.08)$ & 0.36 \\
Lag 0-4 & $0.96(0.86,1.06)$ & 0.39 & $0.94(0.81,1.09)$ & 0.39 \\
Lag 0-5 & $0.96(0.85,1.07)$ & 0.43 & $0.92(0.79,1.09)$ & 0.34 \\
Lag 0-6 & $0.93(0.82,1.05)$ & 0.24 & $0.9(0.76,1.07)$ & 0.24 \\
\hline * The stations are Sheffield Centre (urban) Sheffield Tinsley (industrial) and Ladybower (rural).
\end{tabular}

* The stations are Sheffield Centre (urban), Sheffield Tinsley (industrial) and Ladybower (rural).

A further sensitivity analysis without adjusting for relative humidity was conducted in order to check whether the relatively higher missing rate (about $17 \%$ ) in the humidity data affected the results. However, odds ratio estimates from this analysis were more or less similar to those based on models adjusting for relative humidity (Figure 5). 


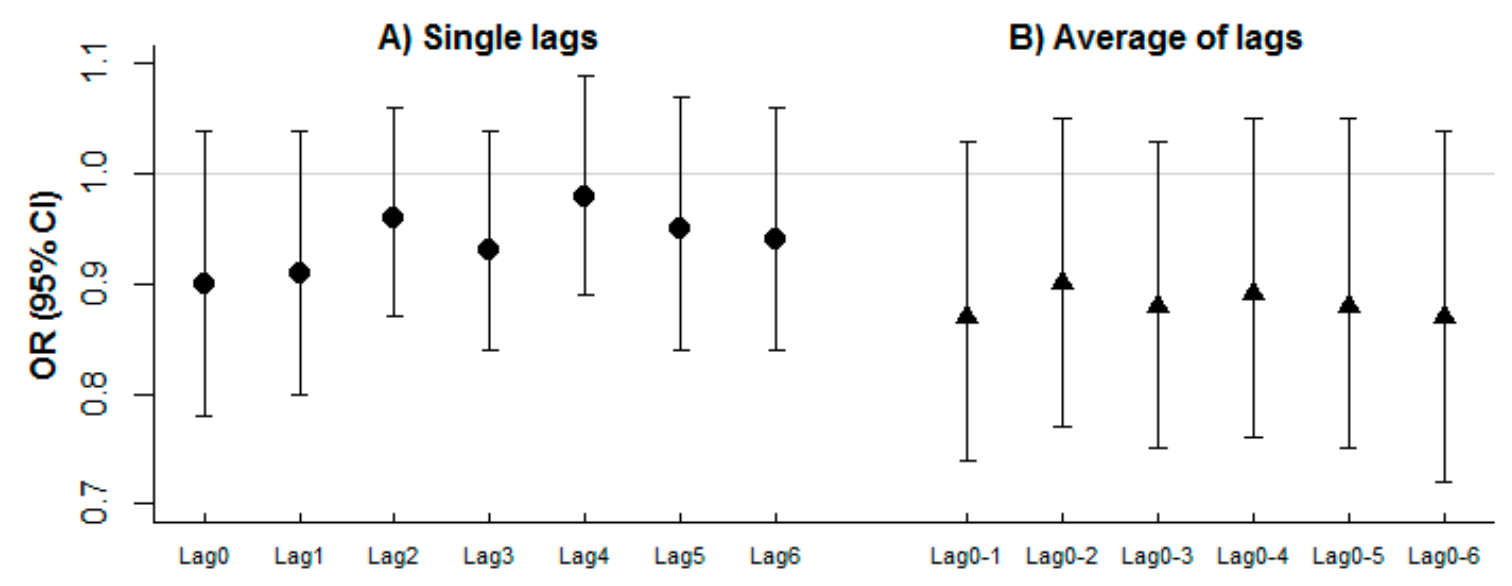

Figure 5. OR (95\% CI) for the association of daily RSV admission and average NO concentrations without controlling for relative humidity. (A) Single lags; (B) Average of lags.

\section{Discussion}

The data generated in this study do not support the suggestion that environmental NO levels may influence the severity of RSV bronchiolitis, and hence hospitalizations rates, amongst infants infected during the annual epidemics. Our findings showed little association between ambient NO and RSV admissions. This was true for the various lags representing short-term exposure as well as analyses both with and without controlling for relative humidity. The latter analyses were conducted because while some studies showed significant association with RSV [7,8], others did not report such a relationship [12]. However, the results should be interpreted with caution due to limitations related to the data.

The daily number of events (RSV admissions) was very low in this data set-the reliability of our results could improve with more data in terms of both time and location. It is generally recommended to have a data set with an average of at least 10 event counts per day and large numbers of days in order to have reasonable power and precision for such environmental exposure studies [38]. Using a simulation-based approach we found the power could range from $62 \%$ to $92 \%$, depending on the specific lag investigated, to detect a $\beta$ coefficient $(\log$ odds $)=0.01$. For example, in the case of the UK, one option would be to use the UK's Royal College of General Practitioners weekly returns data for a national picture with a greater range of exposures and admissions rates. The case-crossover study design applied here to analyse the small data set is a reasonable method to deal with subject-specific confounding and has been successfully used in other epidemiological studies of rare disease outcomes. We found a negative result at the relatively lower NO concentrations that infants in this study were exposed to in comparison to the concentrations in the in vitro studies $[19,21]$. These studies used NO concentrations of $600 \mathrm{ppb}$, which is much higher than typical ambient levels [39].

The combustion of tobacco produces a range of chemicals including NO, and previous studies reported that both antenatal and postnatal exposure to tobacco within the home increases the incidence of hospitalization with RSV [40-44]. However, we believe such exposure to smoking is unlikely to be a confounder in our case-cross over study design, as little temporal variability is expected with respect to smoking status. That is, on average, the smoking behavior of households would not vary much with time.

There may, however, be another contributing factor to the apparent lack of an association observed here; the relative timing of the RSV epidemic and the peak in NO levels. It may be that NO cannot have an effect on RSV pathogenesis unless the two co-exist within a certain time period, say two or three days. If the RSV peak in a given year/area is not associated with particularly high NO then we might not see an effect. If the higher NO levels correspond with the RSV epidemic, this might then be 
associated with a greater number of cases; i.e., $\mathrm{NO}$ acts as a potentiator of severity, as reflected in an increased number of attendances for medical help.

\section{Conclusions}

In summary, while we did not find an association between short-term exposure to ambient NO and RSV admissions, this preliminary study either did not have sufficient power to establish a potentially causal association or the lack of co-incidence of NO and RSV peaks meant that a potentiation of RSV infections was not able to be shown in this dataset.

Acknowledgments: The authors would like to acknowledge the support of Sheffield Children's NHS Foundation Trust in providing data, and funding from Abbott Laboratories and University of Birmingham for support with open access publication.

Author Contributions: Mark L. Everard, Jon G. Ayres, Nicola J. Barker and Ian J. Litchfield conceived and designed the study; Mark L. Everard and Nicola J. Barker performed the experiments; Nuredin I. Mohammed and Ian J. Litchfield analyzed the data; Nuredin I. Mohammed and Ian J. Litchfield drafted the paper. All authors reviewed and contributed to the final draft.

Conflicts of Interest: Ian J. Litchfield was partially funded for this work by the sponsor. The funding sponsors had no role in the design of the study; in the collection, analyses, or interpretation of data; in the writing of the manuscript, and in the decision to publish the results.

\section{Abbreviations}

The following abbreviations are used in this manuscript:

$\begin{array}{ll}\text { RSV } & \text { Respiratory syncytial virus } \\ \text { NO } & \text { Nitrogen Oxide } \\ \text { OR } & \text { Odds ratio }\end{array}$

\section{References}

1. Gibson, G.J.; Loddenkemper, R.; Sibille, Y.; Lundback, B. The European Lung White Book: Respiratory Health and Disease in Europe; European Respiratory Society: Lausanne, Switzerland, 2013.

2. Everard, M.L. Respiratory syncytial virus bronchiolitis and pneumonia. In Pediatric Respiratory Medicine; Taussig, L.M., Ed.; Mosby, Elsevier Health Sciences: St. Louis, MO, USA, 2008; pp. 491-499.

3. Hall, C.B.; Simoes, E.A.; Anderson, L.J. Clinical and epidemiologic features of respiratory syncytial virus. Curr. Top. Microbiol. Immunol. 2013, 372, 39-57. [PubMed]

4. Nair, H.; Nokes, D.J.; Gessner, B.D.; Dherani, M.; Madhi, S.A.; Singleton, R.J.; O’Brien, K.L.; Roca, A.; Wright, P.F.; Bruce, N.; et al. Global burden of acute lower respiratory infections due to respiratory syncytial virus in young children: A systematic review and meta-analysis. Lancet 2010, 375, 1545-1555. [CrossRef]

5. Health Protection Agency. (Archived Content) HPA—Weekly Laboratory Reports of Respiratory Syncytial Virus; Health Protection Agency: London, UK, 2013.

6. Simoes, E.A.F. Environmental and demographic risk factors for respiratory syncytial virus lower respiratory tract disease. J. Pediatr. 2003, 143 (Suppl. 5), 118-126. [CrossRef]

7. Meerhoff, T.J.; Paget, J.W.; Kimpen, J.L.; Schellevis, F. Variation of respiratory syncytial virus and the relation with meteorological factors in different winter seasons. Pediatr. Infect. Dis. J. 2009, 28, 860-866. [CrossRef] [PubMed]

8. Hervas, D.; Reina, J.; Hervas, J.A. Meteorologic conditions and respiratory syncytial virus activity. Pediatr. Infect. Dis. J. 2012, 31, e176-e181. [CrossRef] [PubMed]

9. Ohuma, E.O.; Okiro, E.A.; Ochola, R.; Sande, C.J.; Cane, P.A.; Medley, G.F.; Bottomley, C.; Nokes, D.J. The natural history of respiratory syncytial virus in a birth cohort: The influence of age and previous infection on reinfection and disease. Am. J. Epidemiol. 2012, 176, 794-802. [CrossRef] [PubMed]

10. Clarke, S.K.R.; Gardner, P.S.; Poole, P.M.; Simpson, H.; Tobin, J.O.H. Respiratory syncytial virus infection: admissions to hospital in industrial, urban, and rural areas. Report to the Medical Research Council Subcommittee on Respiratory Syncytial Virus Vaccines. Br. Med. J. 1978, 2, 796-798. 
11. Brandenburg, A.H.; Jeannet, P.Y.; v Steensel-Moll, H.A.; Ott, A.; Rothbarth, P.H.; Wunderli, W.; Suter, S.; Neijens, H.J.; Osterhaus, A.D.; Siegrist, C.A. Local variability in respiratory syncytial virus disease severity. Arch. Dis. Child. 1997, 77, 410-414. [CrossRef] [PubMed]

12. Vandini, S.; Corvaglia, L.; Alessandroni, R.; Aquilano, G.; Marsico, C.; Spinelli, M.; Lanari, M.; Faldella, G. Respiratory syncytial virus infection in infants and correlation with meteorological factors and air pollutants. Ital. J. Pediatr. 2013, 39, 1-6. [CrossRef] [PubMed]

13. Segala, C.; Poizeau, D.; Mesbah, M.; Willems, S.; Maidenberg, M. Winter air pollution and infant bronchiolitis in Paris. Environ. Res. 2008, 106, 96-100. [CrossRef] [PubMed]

14. Karr, C.; Lumley, T.; Schreuder, A.; Davis, R.; Larson, T.; Ritz, B.; Kaufman, J. Effects of subchronic and chronic exposure to ambient air pollutants on infant bronchiolitis. Am. J. Epidemiol. 2007, 165, 553-560. [CrossRef] [PubMed]

15. Karr, C.J.; Rudra, C.B.; Miller, K.A.; Gould, T.R.; Larson, T.; Sathyanarayana, S.; Koenig, J.Q. Infant exposure to fine particulate matter and traffic and risk of hospitalization for RSV bronchiolitis in a region with lower ambient air pollution. Environ. Res. 2009, 109, 321-327. [CrossRef] [PubMed]

16. Derwent, R.G.; Middleton, D.R.; Field, R.A.; Goldstone, M.E.; Lester, J.N.; Perry, R. Analysis and interpretation of air quality data from an urban roadside location in Central London over the period from July 1991 to July 1992. Atmos. Environ. 1995, 29, 923-946. [CrossRef]

17. Bhatt, J.M.; Everard, M.L. Do environmental pollutants influence the onset of respiratory syncytial virus epidemics or disease severity? Paediatr. Respir. Rev. 2004, 5, 333-338. [CrossRef] [PubMed]

18. Jones, A.; Morton, I.; Hobson, L.; Evans, G.S.; Everard, M.L. Differentiation and immune function of human dendritic cells following infection by respiratory syncytial virus. Clin. Exp. Immunol. 2006, 143, 513-522. [CrossRef] [PubMed]

19. Hobson, L.; Everard, M.L. Persistent of respiratory syncytial virus in human dendritic cells and influence of nitric oxide. Clin. Exp. Immunol. 2008, 151, 359-366. [CrossRef] [PubMed]

20. Rivera-Toledo, E.; Gomez, B. Respiratory syncytial virus persistence in macrophages alters the profile of cellular gene expression. Viruses 2012, 4, 3270-3280. [CrossRef] [PubMed]

21. Ugonna, K.; Ugonna, K.; Bingle, C.D.; Plant, K.; Wilson, K.; Everard, M.L. Macrophages are required for dendritic cell uptake of respiratory syncytial virus from an infected epithelium. PLoS ONE 2014, 9, e91855. [CrossRef] [PubMed]

22. Song, W.; Liu, G.; Bosworth, C.A.; Walker, J.R.; Megaw, G.A.; Lazrak, A.; Abraham, E.; Sullender, W.M.; Matalon, S. Respiratory syncytial virus inhibits lung epithelial $\mathrm{Na}^{+}$channels by up-regulating inducible nitric-oxide synthase. J. Biol. Chem. 2009, 284, 7294-7306. [CrossRef] [PubMed]

23. Stark, J.M.; Khan, A.M.; Chiappetta, C.L.; Xue, H.; Alcorn, J.L.; Colasurdo, G.N. Immune and functional role of nitric oxide in a mouse model of respiratory syncytial virus infection. J. Infect. Dis. 2005, 191, 387-395. [CrossRef] [PubMed]

24. Sow, F.B.; Gallup, J.M.; Krishnan, S.; Patera, A.C.; Suzich, J.; Ackermann, M.R. Respiratory syncytial virus infection is associated with an altered innate immunity and a heightened pro-inflammatory response in the lungs of preterm lambs. Respir. Res. 2011, 12, 106. [CrossRef] [PubMed]

25. Mgbemena, V.; Segovia, J.; Chang, T.H.; Bose, S. KLF6 and iNOS regulates apoptosis during respiratory syncytial virus infection. Cell. Immunol. 2013, 283, 1-7. [CrossRef] [PubMed]

26. DEFRA. Air Quality Expert Group. Nitrogen Dioxide in the United Kingdom; Department for Environment, Food and Rural Affairs: London, UK, 2004.

27. UK Meteorological Office. MIDAS Land Surface Stations Data (1853-Current), (Internet). NCAS British Atmospheric Data Centre, 2006. Available online: http://badc.nerc.ac.uk/view/badc.nerc.ac.uk_ATOM_ _dataent_ukmo-midas (accessed on 2 July 2015).

28. Maclure, M. The case-crossover design: A method for studying transient effects on the risk of acute events. Am. J. Epidemiol. 1991, 133, 144-153. [PubMed]

29. Lee, J.T.; Schwartz, J. Reanalysis of the effects of air pollution on daily mortality in Seoul, Korea: A case-crossover design. Environ. Health Perspect. 1999, 107, 633-636. [CrossRef] [PubMed]

30. Jaakkola, J.J. Case-crossover design in air pollution epidemiology. Eur. Respir. J. Suppl. 2003, 40, 81s-85s. [CrossRef] [PubMed] 
31. Pope, C.A., III; Muhlestein, J.B.; May, H.T.; Renlund, D.G.; Anderson, J.L.; Horne, B.D. Ischemic heart disease events triggered by short-term exposure to fine particulate air pollution. Circulation 2006, 114, 2443-2448. [CrossRef] [PubMed]

32. Bhaskaran, K.; Hajat, S.; Armstrong, B.; Haines, A.; Herrett, E.; Wilkinson, P.; Smeeth, L. The effects of hourly differences in air pollution on the risk of myocardial infarction: Case crossover analysis of the MINAP database. BMJ 2011, 343, d5531. [CrossRef] [PubMed]

33. Breslow, N.E.; Day, N.E.; Schlesselman, J.J. Statistical methods in cancer research. Volume I-The analysis of case-control studies. J. Occup. Environ. Med. 1982, 24, 255-257.

34. Armstrong, B.G.; Gasparrini, A.; Tobias, A. Conditional Poisson models: A flexible alternative to conditional logistic case cross-over analysis. BMC Med. Res. Methodol. 2014, 14, 122. [CrossRef] [PubMed]

35. Braga, A.L.; Zanobetti, A.; Schwartz, J. The effect of weather on respiratory and cardiovascular deaths in 12 U.S. cities. Environ. Health Perspect. 2002, 110, 859-863. [CrossRef] [PubMed]

36. Armstrong, B. Models for the relationship between ambient temperature and daily mortality. Epidemiology 2006, 17, 624-631. [CrossRef] [PubMed]

37. R Core Team. R: A Language and Environment for Statistical Computing; R Foundation for Statistical Computing: Vienna, Austria, 2012; ISBN: 3-900051-07-0. Available online: http:/ /www.R-project.org (accessed on 16 October 2012).

38. Bhaskaran, K.; Gasparrini, A.; Hajat, S.; Smeeth, L.; Armstrong, B. Time series regression studies in environmental epidemiology. Int. J. Epidemiol. 2013, 42, 1187-1195. [CrossRef] [PubMed]

39. European Community (EC). Directive 2008/50/EC of the European Parliament and of the Council of 21 May 2008 on ambient air quality and cleaner air for Europe. Off. J. Eur. Union 2008, L152, 1-44.

40. Bradley, J.P.; Bacharier, L.B.; Bonfiglio, J.; Schechtman, K.B.; Strunk, R.; Storch, G.; Castro, M. Severity of respiratory syncytial virus bronchiolitis is affected by cigarette smoke exposure and atopy. Pediatrics 2005, 115, e7-e14. [PubMed]

41. Von Linstow, M.L.; Høgh, M.; Nordbø, S.A.; Eugen-Olsen, J.; Koch, A.; Høgh, B. A community study of clinical traits and risk factors for human metapneumovirus and respiratory syncytial virus infection during the first year of life. Eur. J. Pediatr. 2008, 167, 1125-1133. [CrossRef] [PubMed]

42. DiFranza, J.R.; Masaquel, A.; Barrett, A.M.; Colosia, A.D.; Mahadevia, P.J. Systematic literature review assessing tobacco smoke exposure as a risk factor for serious respiratory syncytial virus disease among infants and young children. BMC Pediatr. 2012, 12, 81. [CrossRef] [PubMed]

43. Carbonell-Estrany, X.; Fullarton, J.R.; Gooch, K.L.; Vo, P.G.; Figueras-Aloy, J.; Lanari, M.; Gouyon, J.B.; Liese, J.G. Effects of parental and household smoking on the risk of respiratory syncytial virus (RSV) hospitalization in late-preterm infants and the potential impact of RSV prophylaxis. J. Matern Fetal Neonatal Med. 2013, 26, 926-931. [CrossRef] [PubMed]

44. Stevenson, M.D.; Mansbach, J.M.; Mowad, E.; Dunn, M.; Clark, S.; Piedra, P.A.; Sullivan, A.F.; Camargo, C.A. Prenatal versus postnatal tobacco smoke exposure and intensive care use in children hospitalized with bronchiolitis. Acad. Pediatr. 2015. [CrossRef] [PubMed]

(C) 2016 by the authors; licensee MDPI, Basel, Switzerland. This article is an open access article distributed under the terms and conditions of the Creative Commons Attribution (CC-BY) license (http://creativecommons.org/licenses/by/4.0/). 